\author{
Małgorzata BARAN ${ }^{1}$ \\ Justyna STECKO ${ }^{2}$
}

\title{
SIMULATION MODEL OF LABOUR FORCE FOR THE MANUFACTURING COMPANY BASED ON SYSTEM DYNAMICS
}

\begin{abstract}
The article presents the methodology of constructing a simulation model of the labour force for a manufacturing company based on the System Dynamics method. The research presented in the article was conducted in three manufacturing companies in Poland. Initially, the key mental model variables of the labour force system were defined. The process of defining the variables was supported by the management as well as by the people directly linked to the labour force management in the manufacturing companies researched. The next step was to combine the variables into a cause - effect diagram, which reflected direct and indirect relationships between particular variables and which allowed to discover some sorts of feedback loops in the system. Next, the cause-effect diagram was converted into a simulation model. To that aim the simulation software, Vensim ${ }^{\circledR}$ was used. After that, validation of the simulation model was conducted using the following methods: assessing the correctness of the boundary of modelling, adequacy of the model structure and adopted values (constants) compared with available knowledge about the modelled system, testing the accuracy and consistency of the units of variables adopted in the model and testing the model behaviour in extreme conditions. The conducted tests confirmed the correctness of the constructed model. Finally, simulation of the model was conducted for the manufacturing companies researched, the results obtained were discussed and final conclusions were formulated. The article finishes with general indications of the direction of the usage of the simulation model presented.

Keywords: simulation modelling, system dynamics, labour force, manufacturing company.
\end{abstract}

\section{INTRODUCTION}

A manufacturing company is a system comprised of a number of minor subsystems. These subsystems include, among others, production, labour force, warehouse management, market, targets and values subsystem, etc. Each subsystem interacts with another subsystem striving for a certain balance determined by the goals of a given manufacturing company. Although these subsystems are highly complex, often times very difficult to grasp by means of human thought models, there are methods which enable one to generally depict processes taking place in these subsystems. One such method is Systems Dynamics. This method allows one to construct simulation models of any selected system as well as particular subsystems. The constructed models present processes taking place in

\footnotetext{
${ }^{1}$ Małgorzata Baran, PhD, Eng, independent researcher, corresponding author: m.baran@poczta.onet.eu

${ }^{2}$ Justyna Stecko, PhD, Department of Humanities, Faculty of Management, Rzeszow University of Technology, Poznańska Str., 1, 35-084 Rzeszów, tel. 017865 1204, e-mail: jstecko@prz.edu.pl
} 
systems both from a quantitative angle as well as from the perspective of the dynamics of their behaviour in time ${ }^{3}$.

The purpose of this article is to present the steps of modelling of the labour force system for the manufacturing company. The investigations that were used to construct the model, were conducted in three manufacturing companies in Poland. The study included observations of subsequent actions determining the appropriate level of employment, indepth interviews with the management of the companies and the study of their source materials. Therefore, the model was based on empirical research.

\section{LITERATURE REVIEW}

Systems dynamics is often used for modelling complex economic systems such as manufacturing companies, in which numerous non-linear relations occur. The very human aspect as a single system, however, hardly ever takes place. The majority of models contain the human aspect as one of the subsystems of bigger systems among other subsystems, for instance production, warehouse management, orders, the market, profits, costs, etc. ${ }^{4}$.

One of the most interesting models devoted to labour force is the model introduced by Sterman ${ }^{5}$ and connected to manufacturing supply chain. The accumulation variables in the model are: "Vacancies" and "Labour." The flow variables are: "Vacancy Creation Rate", "Vacancy Closure Rate", "Hiring Rate" and "Quitting Rate". Among the information variables (or the auxiliary variables) there are, among others: "Desired Vacancy Creation Rate", "Adjustment for Vacancies", "Desired Hiring Rate", "Adjustment for Labour" and "Expected Attrition Rate". The exogenous variable is "Desired Labour". One is able to observe the behaviour of the particular variables of the model in time in response to the various changes of the exogenous variable.

Another interesting model is the model of adjusting employment level to a company's demand introduced by Krupa ${ }^{6}$. The accumulation variables in the model are: "Store" and "Labour". The flow variables are: "Production", "Sale" and "Hiring Rate". There are 8 information variables in the model, among which there are: "Average productivity", "Desired Labour" and "Desired Production". The main objective of the model is to determine the adequate amount of production staff, which undergoes constant changes due to the changes in demand. The model makes it possible to conduct a variety of tests, for

\footnotetext{
3 See more in: J. Forrester, Industrial Dynamics, MIT Press, Cambrigde MA 1961; J. Forrester, Urban Dynamics, MIT Press, Cambrigde MA 1969; J. Forrester, World Dynamics, MIT Press, Productivity Press, 1973; B. Wąsik., Elementy dynamiki systemowej dla ekonomistów, Wydawnictwo Akademii Ekonomicznej, Kraków 1983; K.R. Śliwa, O organizacjach inteligentnych i rozwiąywaniu złożonych problemów zarządzania nimi, Oficyna Wydawnicza WSM SIG, Warszawa 2001; E. Kasperska, Dynamika systemowa. Symulacja i optymalizacja, Wydawnictwo Politechniki Śląskiej, Gliwice 2005; P.M. Senge, Piąta dyscyplina. Teoria $i$ praktyka organizacji uczacych się, Wolters Kluwer Polska, Kraków 2006; Elementy Dynamiki Systemów, red. J. Tarajkowski, Wydawnictwo Akademii Ekonomicznej, Poznań 2008.

4 R. Łukaszewicz, Dynamika systemów zarządzania, PWN, Warszawa 1975; Z. Souček, Modelowanie i projektowanie systemów gospodarczych, Wydawnictwo Naukowe PWN, Warszawa 1979; A. Piekarczyk, K. Zimniewicz, Myślenie sieciowe w teorii i praktyce, PWE, Warszawa 2010.

5 J. Sterman, Business Dynamics: Systems Thinking and Modeling for a Complex World, Irwin McGraw-Hill, Boston 2000, pp. 757-764.

${ }^{6}$ K. Krupa, Modelowanie, symulacja i prognozowanie. Systemy ciagte, Wydawnictwa Naukowo - Techniczne, Warszawa 2008, pp. 92-99.
} 
instance to observe the change in the behaviour of particular variables in response to the change in the "Labour Adjustment Time" variable.

One more model has been introduced by Baran ${ }^{7}$. The model consists of two connected sub models. The task of one of these models is to plan employment in response to the taken orders, while the task of the other one is to present the actual exploitation of the hired labour in particular production processes. The accumulation variables in the model are: "Labour", "Production Labour" and "Finished Stock". The flow variables are: "Desired Hiring Rate", "Labour for Production", "Unexploited Labour", "Production" and "Sale". Among the information variables there are, among others: "Orders", "Demand for Labour", "Average productivity". The model not only serves to determine the number of workers, but also indicates excess employment and shortage of workers. It also allows to conduct tests of the influence of the variables from particular sub models on each other.

\section{ANALYSIS AND STUDY}

The research that was used to construct the model, was conducted in three manufacturing companies in Poland. The study included observations of subsequent actions determining the appropriate level of employment, in-depth interviews with the management of the companies and the study of their source materials. Therefore, the model was based on empirical research.

Profiles of the companies are as follows. Najlepszefoto.pl. was the first company. The company is a medium-sized manufacturing company. It makes products associated with photography, for example photo albums, photo books or photo calendars. The company has operated in the photo market for over a dozen years. It cooperates, among others, with Kodak corporation. The study focused on determining the size of the labour force for production of photo books. The production takes place according to specific orders only. The research in Najlepszefoto.pl was carried out between the second half of September 2009 and the second half of October 2010. It lasted for 56 weeks.

The research was also conducted in Zelgraf company. It represents the sector of small enterprises. The company has been in operation since 1996. It produces professional silicone dies and steel dies for printing, used for decorative glass and plastics marking. The study was focused on determining the size of the workforce for manufacturing silicone stamps (or silicone dies), which make it possible to mark a product on any surface and curvature. As in Najlepszefoto.pl, the production in Zelgraf takes place according to specific orders only. The research in Zelgraf lasted for 60 weeks, between July 2009 and September 2010.

Alfa company is the third company, in which the research was carried out. It is a medium-size clothing company based in the Subcarpathian (Podkarpackie Province). It sews smart, evening trousers for men for the Polish and overseas markets. The production is based on repetition. The study used data from 2006 covering 51 weeks.

Initially, the key mental model variables of the labour force system have been defined. The variables are presented in Table 1.

\footnotetext{
7 M. Baran, Dynamika związków pomiędzy podsystemami produkcji i zatrudnieniem. Przypadek przedsiębiorstwa ALFA. In: A. Nalepka, A. Ujwary - Gil (Ed.), Organizacje komercyjne i niekomercyjne wobec wzmożonej konkurencji oraz wzrastających wymagań konsumentów, SOWA - Drukarnia Cyfrowa, Warszawa 2010, pp. 117-131.
} 
Table 1. Mental model variables of the labour force system

\begin{tabular}{|c|c|}
\hline Variable & Description \\
\hline Inexperienced Workers IW & $\begin{array}{l}\text { The number of newly hired workers who possess certain } \\
\text { skills, however lack the experience }\end{array}$ \\
\hline Hiring rate & The stream of new workers hired \\
\hline Quitting rate IW & $\begin{array}{l}\text { The stream of new workers leaving the job because of being } \\
\text { dismissed by the management of the manufacturing } \\
\text { company, as well as quitting at their own request }\end{array}$ \\
\hline Gaining experience rate & $\begin{array}{l}\text { The number of new workers (per a time unit) who, having } \\
\text { gained experience, are considered as fully capable labour } \\
\text { force }\end{array}$ \\
\hline Gaining experience time & The time to gain experience by new workers \\
\hline $\begin{array}{l}\text { Required number of } \\
\text { inexperienced workers }\end{array}$ & $\begin{array}{l}\text { The variable regulating the pace of hiring new workers } \\
\text { It results from the comparison of "Total demand for workers" } \\
\text { with the number of workers employed in the manufacturing } \\
\text { company }\end{array}$ \\
\hline Total demand for workers & $\begin{array}{l}\text { The number of new workers required to work, resulting } \\
\text { directly from the sum total of the amount of "Required } \\
\text { supply and storage workers" , "Required production workers" } \\
\text { and "Required sales workers" }\end{array}$ \\
\hline Hiring time & The time to adjust the number of workers to the desired level \\
\hline Required production workers & The number of new workers required to production \\
\hline Average productivity & $\begin{array}{l}\text { The average efficiency of experienced workers } \\
\text { It means the quantity of products manufactured by a single } \\
\text { worker in a given time unit }\end{array}$ \\
\hline $\begin{array}{l}\text { Required supply and storage } \\
\text { workers }\end{array}$ & $\begin{array}{l}\text { The number of workers required to work in supply and } \\
\text { storage }\end{array}$ \\
\hline Required sales workers & The number of workers required to work in sales \\
\hline Experienced Workers EW & $\begin{array}{l}\text { The number of experienced workers employed in the } \\
\text { manufacturing company }\end{array}$ \\
\hline Quitting rate EW & $\begin{array}{l}\text { The stream of workers quitting at their own request or due to } \\
\text { retirement age }\end{array}$ \\
\hline Dismissing rate & $\begin{array}{l}\text { The stream of employees dismissed by the management due } \\
\text { to excessive employment }\end{array}$ \\
\hline $\begin{array}{l}\text { Percentage of additional } \\
\text { workers }\end{array}$ & $\begin{array}{l}\text { It indicates the maximum number of excess workers in the } \\
\text { company }\end{array}$ \\
\hline Average notice period for EW & $\begin{array}{l}\text { The time connected to the process of dismissing workers } \\
\text { stipulated by procedures }\end{array}$ \\
\hline Average notice period for IW & The time connected to the process of dismissing new workers \\
\hline
\end{tabular}




\begin{tabular}{|c|l|}
\hline & stipulated by procedures \\
\hline Required production & $\begin{array}{l}\text { The required level of production determined by the size of } \\
\text { orders }\end{array}$ \\
\hline
\end{tabular}

Source: Own elaboration

In the next step a diagram showing direct and indirect cause - effect relationships between variables was constructed (Fig. 1).

Figure 1. Cause - effect diagram of the labour force system

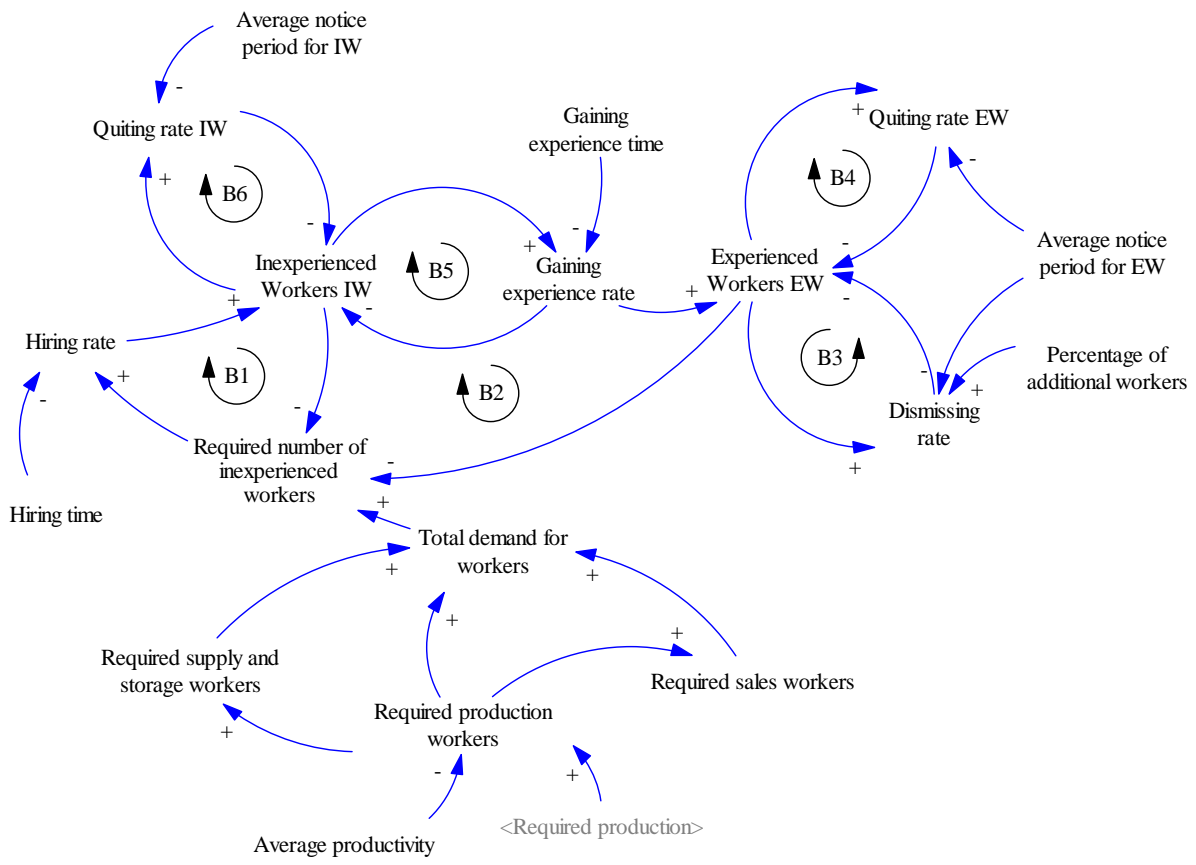

Source: Authors elaboration in Vensim DSS Version 5.9e.

The diagram reflects the process of determining the number of workers which is essential to the production required. The impetus for determining "Total demand for workers" is "Required production", which, together with "Average productivity" initially determines "Required production workers". It was assumed that "Required supply and storage workers" and "Required sales workers" depend on "Required production workers". The sum total of "Required production workers", "Required supply and storage workers" and "Required sales workers" determines "Total demand for workers". This

\footnotetext{
${ }^{8}$ The model assumes that the company owns a fleet of machinery, which is regularly reviewed and maintained so that it is not damaged. This allows us to assume "Average productivity".
} 
demand is compared with the actual number of workers employed and the resultant difference is the cue for "Hiring rate", that is the hiring of new workers.

At the beginning, the newly-hired workers are treated as "Inexperienced Workers IW", who, not being experienced yet, are trained. Some of them leave due to various reasons, e.g. at their own request. It is reflected by "Quitting rate IW" and delayed "Average notice period for IW". The remaining new workers gain the required experience after "Gaining experience time" and are treated as "Experienced Workers EW". "Experienced Workers EW" may also leave work, which is reflected by "Quitting rate EW". It may happen, among others, on their own request or due to retirement age. Workers may also be dismissed on disciplinary grounds. "Dismissing rate" serves a different function. It reflects a situation in which a manufacturing company decides to dismiss excess workers. The amount of dismissed workers is solely the one exceeding the sum total of "Total demand for workers" and "Percentage of additional workers", which is the so-called "labour reserve", which is used in case there is a need to replace workers on leave or sick leave. Dismissals of workers do not occur immediately, but according to "Average notice period for EW".

In the diagram above, six consecutive instances of negative feedback - B1, B2, B3, B4, B5 and B6 were determined, testifying to the existing dynamics in the system.

Next the authors converted the above diagram into a simulation model of the system of labour force (Fig.2). Mental model variables were presented as mathematical variables and constants. The needed coefficients were added. The accumulation, flow variables and auxiliary (information) variables and the mathematical relationships existing between them were indicated. The model was built in the simulation system Vensim DSS Version $5.9 \mathrm{e}$, so the mathematical apparatus was presented with the available functions and mathematical expressions.

There are following accumulation variables in the simulation model:

- "Average notice period for EW" increased by a flow variable "Hiring rate" and reduced by a flow variable "Gaining experience rate";

- "Experienced Workers EW" increased by a flow variable "Gaining experience rate" and reduced by a flow variable "Dismissing rate". 
Figure 2. Simulation model of the labour force system

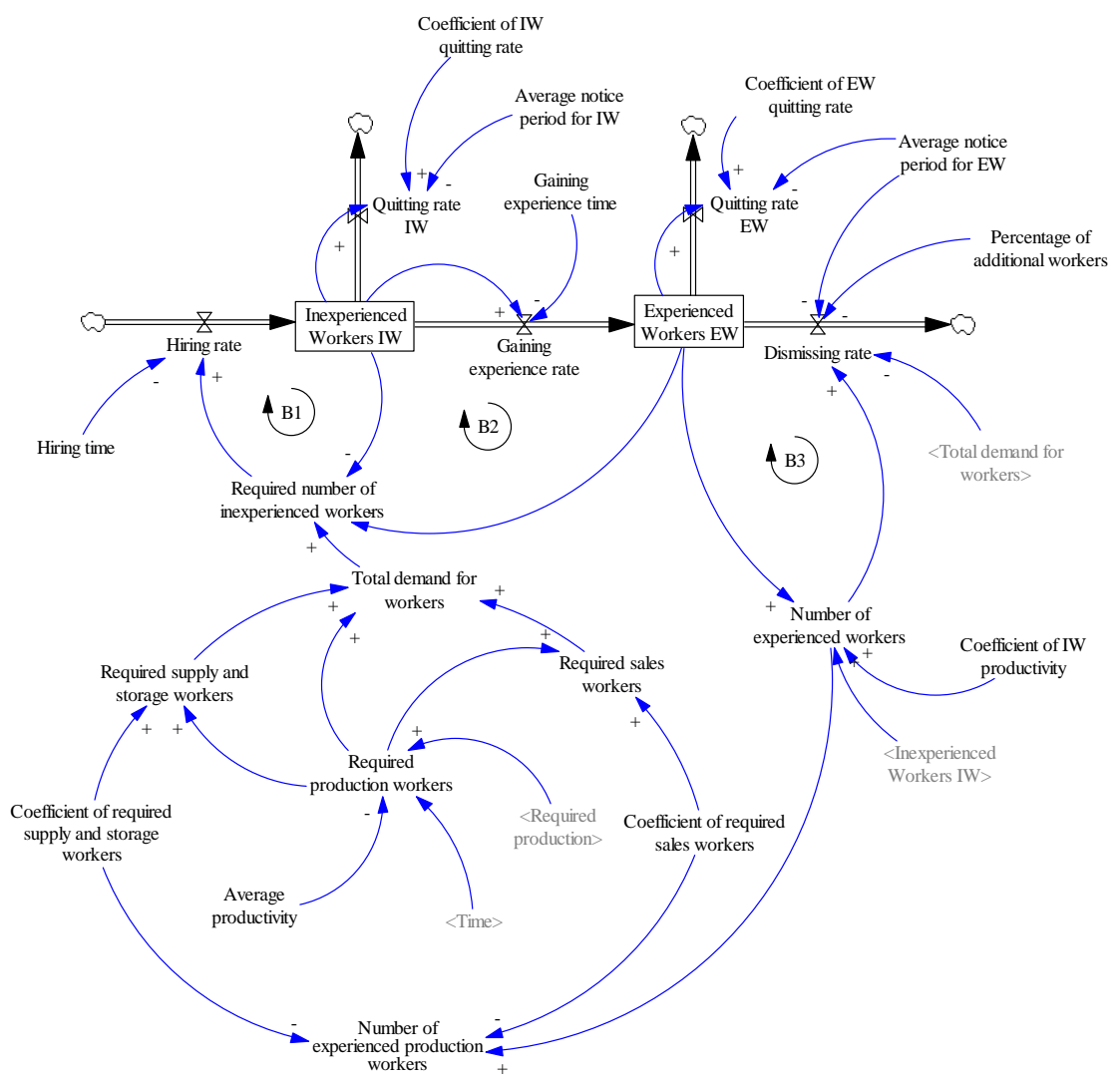

Source: Authors elaboration in Vensim DSS Version 5.9e

Definitions of variables and mathematical constants contained in the simulation model are presented in Table 2.

Table 2. Definitions of variables and mathematical constants of the labour force model

\begin{tabular}{|c|l|c|}
\hline Variable/constant & \multicolumn{1}{|c|}{ Definition } & Unit \\
\hline $\begin{array}{c}\text { Inexperienced Workers } \\
\text { IW }\end{array}$ & $\begin{array}{l}\text { INTEG(Hiring rate-Quitting rate IW-Gaining } \\
\text { experience rate) } \\
\text { Initial value: 0 }\end{array}$ & [person] \\
\hline Hiring rate & $\begin{array}{l}\text { Required number of inexperienced workers/Hiring } \\
\text { time }\end{array}$ & [person/week] \\
\hline Hiring time & The characteristic value for the company & [week] \\
\hline Quitting rate IW & Inexperienced Workers IW*Coefficient of IW & [person/week] \\
\hline
\end{tabular}




\begin{tabular}{|c|c|c|}
\hline & quitting rate/Average notice period for IW & \\
\hline $\begin{array}{l}\text { Coefficient of IW } \\
\text { quitting rate }\end{array}$ & The characteristic value for the company & {$[-]$} \\
\hline $\begin{array}{l}\text { Average notice period } \\
\text { for IW }\end{array}$ & The characteristic value for the company & [week] \\
\hline Gaining experience rate & Inexperienced Workers IW/Gaining experience time & [person/week] \\
\hline $\begin{array}{l}\text { Gaining experience } \\
\text { time }\end{array}$ & The characteristic value for the company & [week] \\
\hline $\begin{array}{l}\text { Required number of } \\
\text { inexperienced workers }\end{array}$ & $\begin{array}{l}\text { MAX }(0,(\text { Total demand for workers-Inexperienced } \\
\text { Workers IW-Experienced Workers EW)) }\end{array}$ & [person] \\
\hline $\begin{array}{l}\text { Total demand for } \\
\text { workers }\end{array}$ & $\begin{array}{l}\text { Required supply and storage workers+Required } \\
\text { production workers+Required sales workers }\end{array}$ & [person] \\
\hline $\begin{array}{l}\text { Required production } \\
\text { workers }\end{array}$ & Required production(Time)/Average productivity & [person] \\
\hline Average productivity & The characteristic value for the company & $\begin{array}{l}\text { [unit/week/per } \\
\text { son] }\end{array}$ \\
\hline $\begin{array}{l}\text { Required supply and } \\
\text { storage workers }\end{array}$ & $\begin{array}{l}\text { Coefficient of required supply and storage } \\
\text { workers*Required production workers }\end{array}$ & [person] \\
\hline $\begin{array}{l}\text { Coefficient of required } \\
\text { supply and storage } \\
\text { workers }\end{array}$ & The characteristic value for the company & {$[-]$} \\
\hline Required sales workers & $\begin{array}{l}\text { Coefficient of required sales workers*Required } \\
\text { production workers }\end{array}$ & [person] \\
\hline $\begin{array}{l}\text { Coefficient of required } \\
\text { sales workers }\end{array}$ & The characteristic value for the company & {$[-]$} \\
\hline $\begin{array}{l}\text { Experienced Workers } \\
\text { EW }\end{array}$ & $\begin{array}{l}\text { INTEG(Experienced Workers EW) } \\
\text { Initial value: Total demand for workers }\end{array}$ & [person] \\
\hline Quitting rate EW & $\begin{array}{l}\text { Experienced Workers EW*Coefficient of EW } \\
\text { quitting rate/Average notice period for EW }\end{array}$ & [person/week] \\
\hline $\begin{array}{l}\text { Coefficient of EW } \\
\text { quitting rate }\end{array}$ & The characteristic value for the company & {$[-]$} \\
\hline Dismissing rate & $\begin{array}{l}\text { IF THEN ELSE(Number of experienced } \\
\text { workers/MAX(1,Total demand for } \\
\text { workers) }>1+\text { Percentage of additional workers/100, } \\
\text { (Number of experienced workers-Total demand for } \\
\text { workers* }(1+\text { Percentage of additional } \\
\text { workers/100))/Average notice period for EW, } 0)\end{array}$ & [person/week] \\
\hline $\begin{array}{c}\text { Percentage of } \\
\text { additional workers }\end{array}$ & The characteristic value for the company & {$[-]$} \\
\hline Average notice period & The characteristic value for the company & [week] \\
\hline
\end{tabular}




\begin{tabular}{|c|l|c|}
\hline for EW & & [person] \\
\hline $\begin{array}{c}\text { Number of experienced } \\
\text { workers }\end{array}$ & $\begin{array}{l}\text { Experienced Workers EW+(Coefficient of IW } \\
\text { productivity*Inexperienced Workers IW) }\end{array}$ & {$[-]$} \\
\hline $\begin{array}{c}\text { Coefficient of IW } \\
\text { productivity }\end{array}$ & The characteristic value for the company & [person] \\
\hline $\begin{array}{c}\text { Number of experienced } \\
\text { production workers }\end{array}$ & $\begin{array}{l}\text { Number of experienced workers/(Coefficient of } \\
\text { required supply and storage workers+Coefficient of } \\
\text { required sales workers+1) }\end{array}$ & \\
\hline
\end{tabular}

Source: Own elaboration.

In the next investigations, the validation of the simulation model was conducted by using the following methods:

- assessing the correctness of the boundary of modelling, adequacy of the model structure and adopted values (constants) compared with available knowledge about the modelled system;

- testing the accuracy and consistency of the units of the variables adopted in the model;

- testing the model behaviour in extreme conditions.

The main objective of building the model was to provide a general representation of labour system in a manufacturing company with key decision rules of controlling this system. Accordingly, variables which could present the system quantitatively were chosen. The executives and experts of the manufacturing companies researched were present during the selection of the variables for the model, as well as during the creation of the model structure. Scientific literature was used, too. The people authorized by management provided the parameter values that were adopted in the model. All parameter values (constants) were averaged by them. All these activities can prove the correctness of the boundary of modelling and the structure of the system and the accuracy of the adopted model parameters.

One of the key measures of determining the correctness of the relationship between the variables in the model, which is also responsible for the overall validity of the model, is to test the cohesion of the units of the variables adopted in the model. The test was conducted directly in the program, in which the model was built, by using the Check Units command. The test confirmed the correctness of the units.

The testing of the model in extreme conditions was to check its behaviour when the values of the constants took an amount equal to 0 or a very large size. The program did not report any errors in the model during the tests.

\section{THE SIMULATION OF THE LABOUR FORCE MODEL}

The following table (Table 3) contains constants obtained from the manufacturing companies studied. 
Table 3. Empirical data from companies studied

\begin{tabular}{|c|c|c|c|}
\hline Constants & Najlepszefoto.pl & Zelgraf & Alpha \\
\hline $\begin{array}{l}\text { Required } \\
\text { production }\end{array}$ & $\begin{array}{l}(0,0)- \\
(56,600)],(0,130),(1, \\
170),(2,227),(3,284), \\
(4,187),(5,185),(6,248) \\
,(7,216),(8,166),(9,150 \\
),(10,148),(11,155),(12 \\
, 139),(13,184),(14,113 \\
),(15,120),(16,127),(17 \\
, 156),(18,116),(19,115 \\
),(20,129),(21,128),(22 \\
, 136),(23,156),(24,162 \\
),(25,194),(26,198),(27 \\
, 162),(28,223),(29,231 \\
),(30,259),(31,379),(32 \\
, 272),(33,279),(34,420 \\
),(35,490),(36,356),(37 \\
, 312),(38,307),(39,321 \\
),(40,336),(41,331),(42 \\
, 342),(43,337),(44,352 \\
),(45,346),(46,329),(47 \\
, 352),(48,458),(49,350 \\
),(50,352),(51,368),(52 \\
, 321),(53,296),(54,290 \\
),(55,349),(56,284)\end{array}$ & $\begin{array}{l}{[(0,0)-} \\
(61,55)],(0,12),(1,17),(2, \\
10),(3,12),(4,24),(5,8),(6 \\
, 5),(7,20),(8,16),(9,31),( \\
10,7),(11,5),(12,8),(13, \\
19),(14,6),(15,27),(16,12 \\
),(17,5),(18,5),(19,13), \\
(20,5),(21,21),(22,23), \\
(23,5),(24,0),(25,0),(26, \\
0),(27,4),(28,11),(29,3), \\
(30,9),(31,12),(32,7),(33 \\
17),(34,24),(35,21),(36, \\
4),(37,5),(38,10),(39,35) \\
,(40,14),(41,8),(42,14), \\
(43,42),(44,0),(45,23), \\
(46,13),(47,5),(48,9),(49 \\
, 6),(50,2),(51,38),(52,15 \\
),(53,10),(54,0),(55,14),( \\
56,10),(57,16),(58,26),(5 \\
9,51),(60,13)\end{array}$ & $\begin{array}{l}{[(0,0)-} \\
(56,230)],(0,61),(1,135), \\
(2,0),(3,8),(4,29),(5,10), \\
(6,47),(7,37),(8,87),(9, \\
76),(10,61),(11,185),(12, \\
169),(13,216),(14,72), \\
(15,118),(16,79),(17,143 \\
),(18,69),(19,128),(20,58 \\
),(21,35),(22,73),(23,29) \\
,(24,59),(25,0),(26,0), \\
(27,0),(28,35),(29,25), \\
(30,52),(31,83),(32,114), \\
(33,15),(34,72),(35,92),( \\
36,81),(37,85),(38,99), \\
(39,80),(40,103),(41,120 \\
),(42,93),(43,129),(44, \\
122),(45,92),(46,74),(47, \\
105),(48,228),(49,166), \\
(50,151),(51,0)\end{array}$ \\
\hline Hiring time & 2 & 6 & 0.02 \\
\hline $\begin{array}{l}\text { Coefficient } \\
\text { of IW } \\
\text { quitting rate }\end{array}$ & 0.06 & 0.02 & 0.01 \\
\hline $\begin{array}{l}\text { Gaining } \\
\text { experience } \\
\text { time }\end{array}$ & 4 & 6 & 0.02 \\
\hline $\begin{array}{l}\text { Average } \\
\text { productivity }\end{array}$ & 19 & 7 & 50 \\
\hline $\begin{array}{l}\text { Coefficient } \\
\text { of required } \\
\text { supply and } \\
\text { storage } \\
\text { workers }\end{array}$ & 0.04 & 0.04 & 0.06 \\
\hline $\begin{array}{l}\text { Coefficient } \\
\text { of required } \\
\text { sales } \\
\text { workers }\end{array}$ & 0.04 & 0.03 & 0.03 \\
\hline
\end{tabular}




\begin{tabular}{|l|l|l|l|}
\hline $\begin{array}{l}\text { Coefficient } \\
\text { of EW } \\
\text { quitting rate }\end{array}$ & 0.02 & 0.01 & 0.01 \\
\hline $\begin{array}{l}\text { Percentage } \\
\text { of } \\
\text { additional } \\
\text { workers }\end{array}$ & 20 & 100 & 10 \\
\hline $\begin{array}{l}\text { Coefficient } \\
\text { of IW } \\
\text { productivity }\end{array}$ & 0.7 & 0.5 & 1 \\
\hline $\begin{array}{l}\text { Average } \\
\text { notice } \\
\text { period for } \\
\text { IW }\end{array}$ & 1 & 1 & 1 \\
\hline $\begin{array}{l}\text { Average } \\
\text { notice } \\
\text { period for } \\
\text { EW }\end{array}$ & 4 & 12 & 4 \\
\hline
\end{tabular}

Source: Own elaboration.

After completing the model data obtained in the investigated enterprises, the simulation of the model was conducted. The 0.015625 simulation step was set. The runs of accumulation variables are shown in Figure 3.

Figure 3. Runs of accumulation variables in the investigated enterprises

\section{In Najlepszefoto.pl}

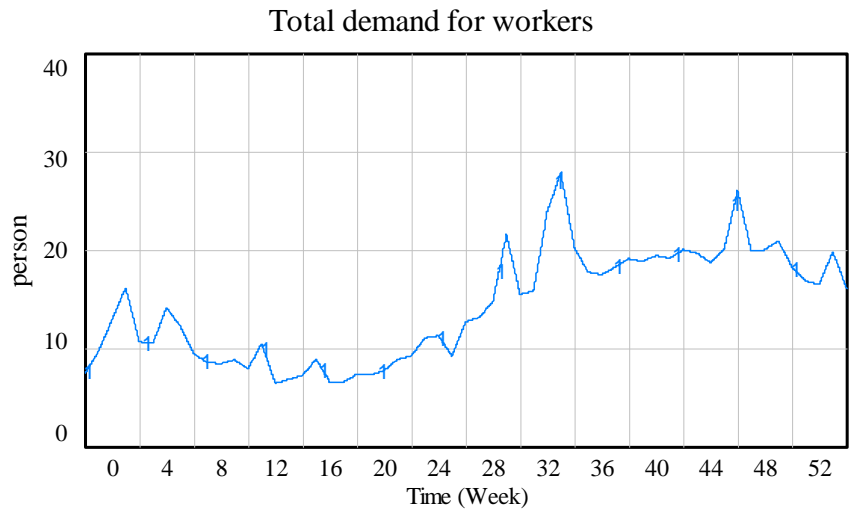

Total demand for workers : Current $\begin{array}{llllll}1 & 1 & 1 & 1 & 1 & 1\end{array}$ 


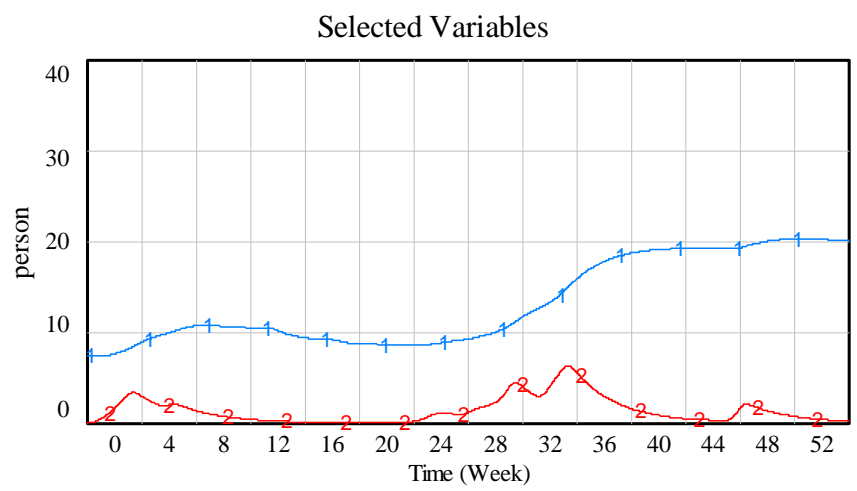

Experienced Workers EW : Current -1 $1141-1141$ Inexperienced Workers IW : Current $\begin{array}{llllllll}2 & 2 & 2 & 2 & 2 & 2\end{array}$

\section{In Zelgraf}

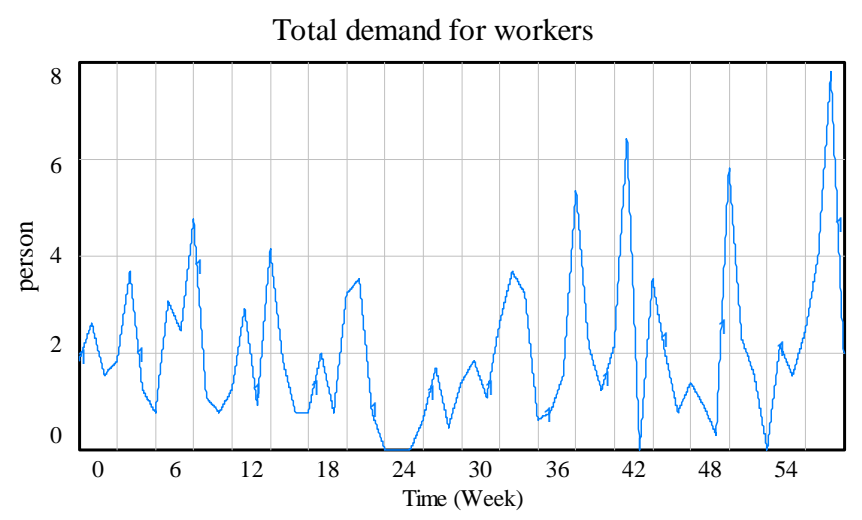

Total demand for workers : Current $\begin{array}{llllll}1 & 1 & 1 & 1 & 1 & 1\end{array}$

Selected Variables

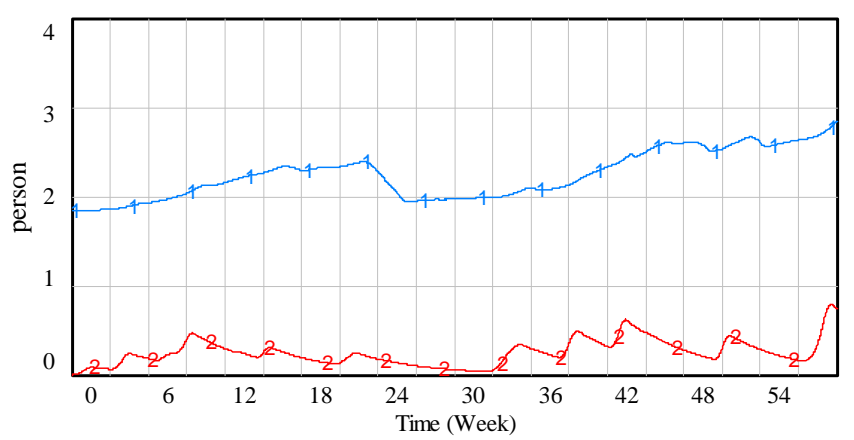

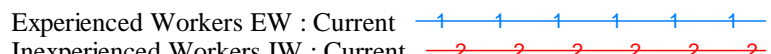

Inexperienced Workers IW : Current $\begin{array}{lllllll}2 & 2 & 2 & 2 & 2 & 2\end{array}$ 


\section{In Alfa}

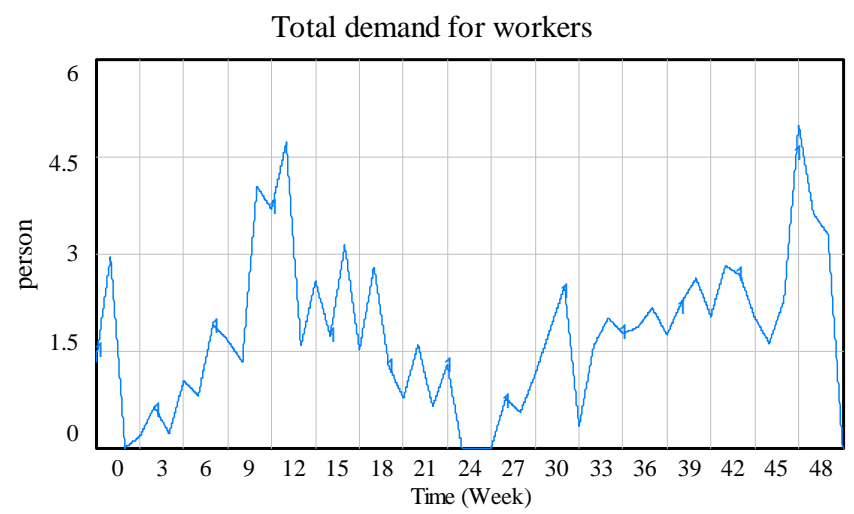

Total demand for workers : Current

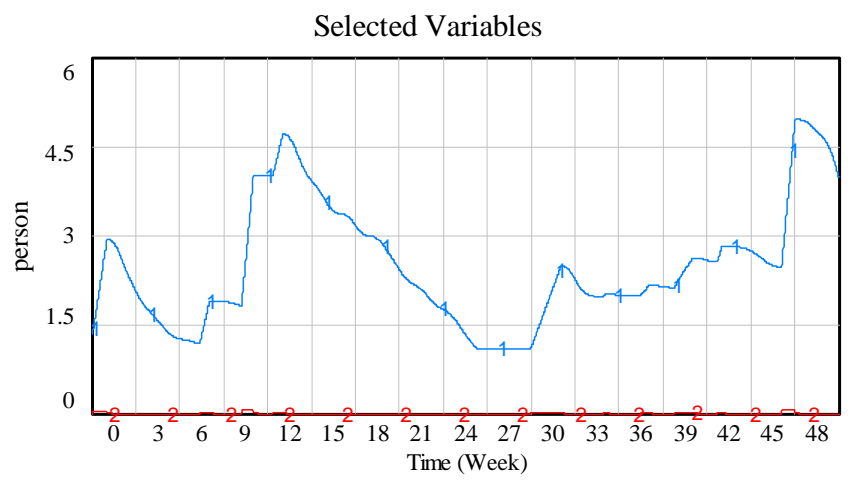

Experienced Workers EW : Current

Inexperienced Workers IW : Current $\begin{array}{lllllll}2 & 2 & 2 & 2 & 2 & 2\end{array}$

Source: Authors elaboration in Vensim DSS Version 5.9e

The runs of such variables as "Total demand for workers", "Experienced Workers EW" and "Inexperienced Workers IW" in response to the "Required production" are shown in the graphs above for each of the manufacturing companies investigated. The variable "Total demand for workers" determines the total number of workers, including the immediate production, supply, storage and sales workers. In the case of Najlepszefoto.pl manufacturing company, the run of the variable is less rapid than in the two following cases. This results directly from the less significant leaps of production over time in this company. Both in the case of Zelgraf and Alfa manufacturing companies there were such periods of time for which the value of "Total demand for workers" amounted to 0 . This is the time when the manufacturing companies had holiday breaks and the volumes of production also amounted to 0 . 
The accumulation variables show the number of both experienced and inexperienced workers in the investigated manufacturing companies. In the case of Najlepszefoto.pl and Zelgraf manufacturing companies the runs of the variable "Experienced Workers EW" are characterised by mild increases, while the values of the variable "Inexperienced Workers IW" are subject to constant fluctuations due to changes in the volumes of production and the fact that inexperienced workers gain the status of experienced workers over time. In Alfa company the run of the variable "Experienced Workers EW" is more dynamic, which is also related directly to changes in the volumes of production, while the values of the variable "Inexperienced Workers IW" may be said to amount to 0 . This is related to the fact that the company did not need new workers because the study included only one assortment of its production delegated to already employed workers.

\section{CONCLUSION}

The simulation model of the labour force for the manufacturing company was constructed using the Systems Dynamics method. In order to construct the model, variables indicated by the management of the investigated manufacturing companies or by the people selected by the managerial staff. Their key mental models were verbalised and initially shown as cause - effect diagrams. Next the diagrams were converted into a simulation model, which was then tested. The final form of the model has been presented in this article.

Currently the model can be used for the following purposes:

$>$ forecasting the size of the workforce in response to the required production

$>$ discovering correlations between variables which build the system of labour force

$>$ testing strategies related to the management of workforce before their practical implementation

$>$ predicting the effects of decision - making processes in the short and long term

$>$ training young managers

The model can also be adopted by other manufacturing companies after adjusting it to the conditions and the environment of these companies.

\section{REFERENCES}

[1] Baran M., Dynamika związów pomiędzy podsystemami produkcji i zatrudnieniem. Przypadek przedsiębiorstwa ALFA [w:] A. Nalepka, A. Ujwary - Gil (Ed.), Organizacje komercyjne i niekomercyjne wobec wzmożonej konkurencji oraz wzrastających wymagań konsumentów, SOWA - Drukarnia Cyfrowa, Warszawa 2010.

[2] Forrester, J., Industrial Dynamics, Cambrigde: MIT Press 1961.

[3] Forrester, J., Urban Dynamics, Cambrigde: MIT Press 1969.

[4] Forrester, J., Principles of Systems, Cambrigde: MIT Press 1981.

[5] Kasperska, E., Dynamika systemowa. Symulacja i Optymalizacja, Wydawnictwo Politechniki Śląskiej, Gliwice 2005.

[6] Krupa K., Modelowanie, symulacja i prognozowanie. Systemy ciagłe, Wydawnictwo Naukowo - Techniczne, Warszawa 2008.

[7] Łukaszewicz, R., Dynamika systemów zarządzania, PWN, Warszawa 1975.

[8] Piekarczyk A., Zimniewicz K., Myślenie sieciowe w teorii i praktyce, PWE, Warszawa 2010.

[9] Senge, P.M., Piata dyscyplina. Teoria $i$ praktyka organizacji uczacych sie, Oficyna Ekonomiczna Wolters Kluwer Polska, Kraków 2006. 
[10] Śliwa, K. R., O Organizacjach Inteligentnych i rozwiąywaniu złożonych problemów zarzqdzania nimi, Oficyna Wydawnicza WSM SIG, Warszawa 2001.

[11] Souček, Z., Modelowanie i Projektowanie Systemów Gospodarczych, PWE, Warszawa 1979.

[12] Sterman, J., Business Dynamics: Systems Thinking and Modeling for a Complex World, Irwin McGraw-Hill, Boston 2000.

[13] Tarajkowski, J. (Ed.)., Elementy Dynamiki Systemów, Wydawnictwo Akademii Ekonomicznej, Poznań 2008.

[14] Wąsik, B., Elementy dynamiki systemowej dla ekonomistów, Wydawnictwo Akademii Ekonomicznej, Kraków 1983.

\section{SYMULACYJNY MODEL SILY ROBOCZEJ ZATRUDNIANEJ W PRZEDSIEBIORSTWIE PRODUKCYJNYM OPRACOWANY W KONWENCJI METODY DYNAMIKI SYSTEMÓW}

Artykuł prezentuje metodykę konstruowania symulacyjnego modelu siły roboczej zatrudnianej w przedsiębiorstwie produkcyjnym. Metodyka oparta jest o metodę Dynamiki Systemów. Badania przedstawione w artykule przeprowadzono w trzech polskich przedsiębiorstwach. Początkowo wyznaczono kluczowe zmienne związane $\mathrm{z}$ modelem myślowym. Skorzystano w tym etapie w wiedzy kierownictwa oraz osób bezpośrednio odpowiedzialnych za siłę roboczą w danym przedsiębiorstwie. Kolejnym krokiem było powiązanie wyznaczonych zmiennych w diagramy przyczynowo skutkowe, co pozwoliło na przedstawienie bezpośrednich i pośrednich powiązań pomiędzy zmiennymi oraz odkrycie rodzajów sprzężeń zwrotnych występujących w systemie. Następnie diagram przyczynowo - skutkowy przekonwertowano na model symulacyjny, wykorzystując przy tym oprogramowanie Vensim®. Dokonano także walidacji zaproponowanego modelu wykorzystując takie metody jak: oszacowanie poprawności granic modelowania oraz poprawności struktury modelu razem $\mathrm{Z}$ wyznaczonymi zmiennymi w oparciu o dostępną wiedzę o modelowanym systemie; testowanie poprawności przyjętych jednostek opisujących poszczególne zmienne oraz testowanie zachowania się modelu w warunkach ekstremalnych. Metody walidacji potwierdziły poprawność przedstawionego modelu. W końcowym etapie przeprowadzono symulację modelu dla badanych przedsiębiorstw oraz omówiono otrzymane wyniki. Artykuł kończą ogólne wskazania związane z użytkowaniem modelu.

Słowa kluczowe: modelowanie symulacyjne, Dynamika Systemów, siła robocza, przedsiębiorstwo produkcyjne.

\section{DOI: 10.7862/rz.2015.mmr.50}

Tekst złożono w redakcji: wrzesień 2015

Przyjęto do druku: grudzień 2015 